\title{
The overlapping continuum of host range among strains in the Pseudomonas syringae complex
}

\author{
Cindy E. Morris ${ }^{1 *} \mathbb{D}$, Jay Ram Lamichhane ${ }^{1,2}$, Ivan Nikolić ${ }^{3}$, Slaviša Stanković ${ }^{3}$ and Benoit Moury
}

\begin{abstract}
Pseudomonas syringae is the most frequently emerging group of plant pathogenic bacteria. Because this bacterium is ubiquitous as an epiphyte and on various substrates in non-agricultural settings, there are many questions about how to assess the risk for plant disease posed by strains in the environment. Although $P$. syringae is considered to have discrete host ranges in defined pathovars, there have been few reports of comprehensive comparisons of host range potential. Here we present results of host range tests for 134 strains, representing eight phylogroups, from epidemics and environmental reservoirs on 15 to 22 plant species per test conducted in four separate tests to determine the patterns and extent of host range. We sought to identify trends that are indicative of distinct pathotypes and to assess if strains in the $P$. syringae complex are indeed restricted in their host range. We show that for each test, strains display a diversity of host ranges from very restricted to very broad regardless of the gamut of phylogroups used in the test. Overall, strains form an overlapping continuum of host range potential with equal representation of narrow, moderate and broad host ranges. Groups of distinct pathotypes, including strains with currently the same pathovar name, could not be identified. The absence of groupings was validated with statistical tests for pattern recognition. The extent of host range was positively correlated with the capacity of strains to swarm on semi-solid agar medium and with the abundance of genes in biosynthetic clusters and was inversely correlated with the abundance of genes for proteins with transmembrane domains in their genomes. Our results are consistent with the current paradigm that disease symptoms are the result of multiple molecular interactions between $P$. syringae and its plant host that are modulated by abiotic and biotic conditions. This leads us to propose that pathovar denominations do not correspond to the underlying biology of P. syringae. A new concept of pathogenicity that accounts for the continuum of pathogenic potential in $P$. syringae would open new perspectives to understand the evolution of pathogenicity in this bacterium and new insights to anticipate disease and to manage plant health.
\end{abstract}

Keywords: Emergence, Network analysis, Pathovar, Artificial inoculation, Swarming motility

\section{Background}

Bacteria in the Pseudomonas syringae complex regularly cause new disease epidemics of herbaceous and woody crops throughout the world (Lamichhane et al. 2014; Lamichhane et al. 2015). According to "First Reports" of plant diseases published in the Plant Disease journal over ca. the past 3 years (Jan. 2015 to July 2018), reports of diseases caused by strains in the $P$. syringae complex are more frequent than those for diseases caused by any

\footnotetext{
* Correspondence: cindy.morris@inra.fr

${ }^{1}$ Plant Pathology Research Unit 407, PACA Research Center, INRA, Montfavet 84143, France

Full list of author information is available at the end of the article
}

other group of plant pathogenic bacteria and are more or equally frequent as those for certain fungi (Fig. 1). When new crop diseases occur, diagnosis can provide practical information useful for implementing efficient control measures in the current cropping season and in limiting future disease outbreaks. This includes information about capacity of the pathogen to adapt to climatic conditions, sensitivity to biocides and biocontrol agents, about its virulence on the range of available cultivars of the crop, and about potential reservoirs and sources of inoculum. This information facilitates decisions concerning the use of biocides, biocontrol agents, resistant varieties and cultural practices so as to avoid inoculum

(c) The Author(s). 2019 Open Access This article is distributed under the terms of the Creative Commons Attribution 4.0 International License (http://creativecommons.org/licenses/by/4.0/), which permits unrestricted use, distribution, and 


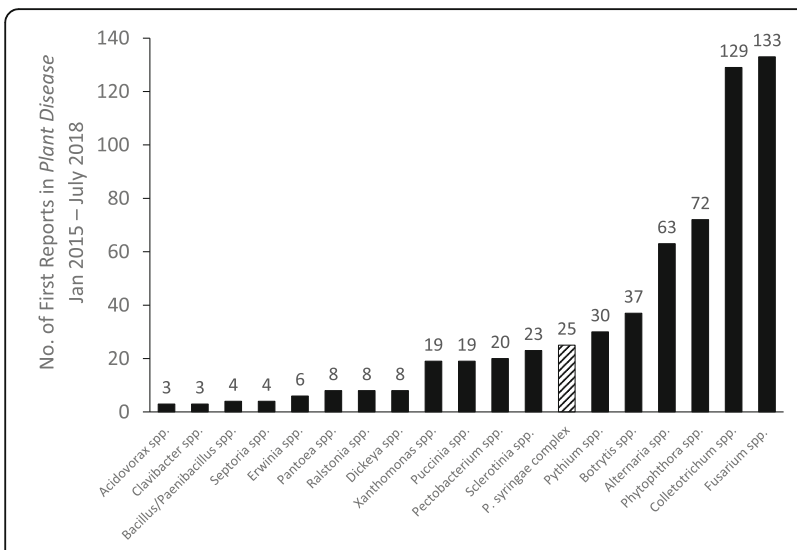

Fig. 1 Number of First Reports in the journal Plant Disease, from Jan 2015 to July 2018, than concern species in the Pseudomonas syringae complex (hashed bar) relative to other pathogens (black bars) in a total of 1862 reports

and the favorable conditions for disease. For diseases caused by $P$. syringae, agronomic practices to avoid inoculum sources and the conditions that are favorable to disease are the most relied-upon means of control (Lamichhane et al. 2014; Lamichhane et al. 2015). Therefore, knowledge of traits relative to the aptitude to survive in various reservoirs or to spread to other crops is particularly pertinent for implementing preventive measures as well as for the spatial and temporal organization of crops in polyculture.

Among the numerous reports of disease emergence due to $P$. syringae, several suggest that the pathogen originated from epidemics on plant genera or species different from that on which emergence was reported. For example, the strains of $P$. syringae causing a new leaf spot on kale in California were considered to be a tomato pathogen (Koike et al. 2017). Tomato has been reported to be a common host of a range of pathovars of $P$. syringae that attack crucifers including strains called pv. maculicola, pv. appi and pv. antirrhini (Hendson et al. 1992). Likewise, bristle oats planted as a green manure in fields cultivated to crucifers in Japan developed a brown spot disease caused by strains that were previously described as $P$. syringae pv. alisalensis-pathogenic to crucifers (Ishiyama et al. 2013). Pathogenicity of $P$. syringae pv. alisalensis strains to bristle oats and to other graminaceous crops and green manures such as oats and timothy has also been reported elsewhere (Cintas et al. 2002). Sugar beet has been observed to be a common host for various strains that cause disease to cucurbits (Morris et al. 2000; Sedighian et al. 2014) leading to suggestions that epidemics on beets are inoculum sources for cucurbits. For a blight of coffee seedlings that emerged in the state of São Paulo, Brazil in 2006, strains that caused the disease had PCR-RFLP profiles identical to those of the type strain of $P$. syringae pv. tabaci but not of the known coffee pathogen $P$. syringae pv. garcae (Destéfano et al. 2010). In another example, emergence in Italy of bacterial blight on the ornamental tree White Bird of Paradise (Strelitzia augusta) was attributed to strains of $P$. s. pv. lachrymans and were also virulent on zucchini (Polizzi et al. 2005). Furthermore, for several diseases caused by $P$. syringae, the bacterial populations associated with epidemics are genetically very diverse and the strains are virulent on a range of plant species. Strains identified as P. syringae pv. pisi that cause blight on pea are genetically very diverse and have varying host ranges in laboratory tests. Furthermore, in these tests some of the most aggressive strains on pea were those closely related to strains from pea but that had been isolated from other diseased plants including lilac, common bean, hairy vetch and cantaloupe (Martin-Sanz et al. 2013). Several independent studies on $P$. syringae causing blights to cucurbits have revealed that there is a wide genetic diversity of strains from epidemics to cantaloupe, squash and watermelon and that the strains are virulent to numerous cucurbit species as well as to other herbaceous plants (Morris et al. 2000; Sedighian et al. 2014; Newberry et al. 2016). These examples raise questions about the extent of cross contaminations and spill over. Knowledge of the potential for spill over could guide agricultural practices to avoid reservoirs of inoculum.

Managing or avoiding reservoirs of $P$. syringae has been complicated by accumulating data that this bacterium is present in various substrates that are nearby or that can come into contact with crops. These substrates include rainfall (Monteil et al. 2014), irrigation waters and their sources (Riffaud and Morris 2002; Monteil et al. 2013), symptomless weeds, wild plants and ground covers (Malvick and Moore 1988; Hirano and Upper 2000; Morris et al. 2008). The strains from these substrates had traits common to strains from diseased plants including a functional Type 3 Secretion System able to induce hypersensitivity in tobacco and the capacity to provoke disease symptoms on a range of plants in greenhouse tests. The prevalence of potentially pathogenic strains of $P$. syringae in non-plant substrates such as irrigation waters or in symptomless weeds, wild plants and ground covers raises the obvious question of the risk they pose for crops. In the case of hazelnut canker, for example, wild relatives of cultivated hazelnut are thought to be the source of at least two distinct genetic lines of $P$. syringae that have caused damage to hazelnut orchards (O'Brien et al. 2012). Likewise, all of the examples cited in the preceding paragraph suggest that green manures, crops in rotation or nearby crops can also be sources of inoculum for disease.

Accounting for the breadth of host range of a pathogen-viz. whether it is a specialist or is a generalist-is seen as one of the future challenges for modeling disease epidemics (Cunniffe et al. 2015). In epidemiological models 
the number of different hosts to which a pathogen causes disease influences the spatial density and distribution of the host landscape. Increasing host density increases the ease for a pathogen to be invasive (Madden and Van Den Bosch 2002). Hence, for a generalist there could be a greater effective density of susceptible host tissue available-if the plants in its host range were cultivated at the same time-and therefore generalists would have a greater potential for invasion and emergence than would specialists. Although the influence of host range on disease epidemiology can be formalized mathematically, this influence is also reflected in age-old strategies to manage diseases caused by generalists (such as the soft rot enteric bacteria, for example) that rely mostly on avoidance and hygiene vs. those caused by obligate, host specific organisms (such as rust fungi) where deployment of resistant plant varieties can be very effective.

It is not well established to what extent strains of $P$. syringae are generalists or specialists. $P$. syringae has often been described as having a broad host range collectively for the species complex but that its individual genetic lines generally have a restricted host range (Sarkar et al. 2006; Lindeberg et al. 2009; Baltrus et al. 2011; Mucyn et al. 2014). This notion of restricted host range refers to the fact that there are few reports of the same strain being isolated from epidemics on different crop species. The paucity of such reports might not necessarily be due solely to the inherent host range limitation of any particular strain. A likely contributing factor is the lack of efforts to compare the genomes of strains from new epidemics with that of strains in collections from previous epidemics. This possibility is technically feasible now, but this has not always been the case. Another contributing factor could also be a hitherto lack of opportunity for encounters with certain susceptible hosts under conducive conditions. The paucity of reports is probably also attributable to the extensive diversity and ubiquity of $P$. syringae. This bacterial group has a global metapopulation of at least $10^{22}$ cells and the number of different genetic lines is likely to be only a few orders of magnitude smaller than the total number of cells (Morris et al. 2010; Morris et al. 2013). These traits of the metapopulation have two consequences on disease etiology. Firstly they lead to the high genetic diversity of strains that cause epidemics on a same host. Secondly they make it highly improbable that a same clone would be found in diverse situations. An exception would be the case where vegetative propagation of the host leads to widespread dissemination of a clonal line as in the case of kiwifruit canker. In spite of the many reports that characterize the pathogenicity of $P$. syringae, comprehensive evaluation of the host range potential of $P$. syringae strains under comparable conditions is lacking.

The objective of this work is to assess the patterns in an ensemble of host range data that we have collected for $P$. syringae over the past decades in inoculation trials. We sought to identify trends that are indicative of distinct pathotypes and to assess if strains in the P. syringae complex are indeed restricted in their host range. The data here represent four host range tests conducted in 1998 (test A), 2008 (test B), 2013 (test C) and 2017 (test D) for a collective total of 134 strains from epidemics and environmental reservoirs on 15 to 22 plant species per test.

\section{Results \\ Variability of plant-bacterial interactions}

For all strains and plant species considered together, inoculation of any given plant species frequently resulted in a reaction that could be considered as a disease symptom. For herbaceous plants, $40 \%$ to $80 \%$ of inoculations resulted in symptom expression and for woody plants $33 \%$ and $65 \%$ of the inoculations resulted in external or internal lesions, respectively, for at least one of the replicate plants, depending on the test (Table 1). Inoculations that resulted in symptoms for only one of the replicate plants represented less than $17 \%$ of the inoculations for external symptoms for tests C and D and $26 \%$ of the inoculations for internal symptoms on woody plants. For tests $\mathrm{A}$ and $\mathrm{B}$, inoculations resulted in symptoms for only one replicate plant in up to $49 \%$ of the inoculations. The regularity of symptom expression depended on the test. In tests $C$ and $D, 74 \%$ to $94 \%$ of the inoculations that resulted in disease symptoms for at least one replicate plant also resulted in symptoms for at least half of the plants (Table 1). In tests A and B, $51 \%$ to $62 \%$ of symptom expression were cases where at least half of the plants had symptoms (Table 1 ). Tests $C$ and D were each conducted in a shorter period of time representing more homogenous environmental conditions in the greenhouse than tests $\mathrm{A}$ and $\mathrm{B}$.

The host range of strain CC0094 was evaluated multiple times: in test A as part of the initial determination of its host range, as a control strain in test D, and was part of four independent trials with the 16 different species deployed as a control in test B. In test B the pathogenicity of CC0094 was identical on 14 of the 16 plant species among the four independent trials and showed variable results on tomato (Solanum lycopersicum) and eggplant (S. melongena) (Table 2). When tests A, B and $\mathrm{D}$ were considered collectively, there were at least 17 plant species (not considering botanical variety or cultivar) where the host range of CC0094 was examined at least 2 times. The pathogenicity of CC0094 was identical for 11 of these species among the different tests.

Ten other strains were also used in more than one test. B728A was used in tests A and B that had 16 plant species in common. In tests $\mathrm{A}$ and $\mathrm{B}, \mathrm{B} 728 \mathrm{~A}$ caused symptoms on at least 3 of 6 replicate plants of peas, 
Table 1 Variability in the response of plants to inoculation with strains of Pseudomonas syringae for each of the four tests and for woody and herbaceous plants

\begin{tabular}{|c|c|c|c|c|c|c|}
\hline Test & A-1998 & B-2003 & $C-2013$ & $C-2013$ & $C-2013$ & D-2017 \\
\hline Type of plants & $\begin{array}{l}\text { Herbaceous } \\
\text { annual }\end{array}$ & $\begin{array}{l}\text { Herbaceous } \\
\text { annual }\end{array}$ & $\begin{array}{l}\text { Herbaceous } \\
\text { annual }\end{array}$ & $\begin{array}{l}\text { Woody perennial } \\
\text { (external symptoms) }\end{array}$ & $\begin{array}{l}\text { Woody perennial } \\
\text { (internal symptoms) }\end{array}$ & $\begin{array}{l}\text { Herbaceous } \\
\text { annual }\end{array}$ \\
\hline No. of bacterial strains & 45 & 44 & 38 & 38 & 38 & 20 \\
\hline No. of plant species tested & 18 & 16 & 12 & 10 & 10 & 16 \\
\hline $\begin{array}{l}\text { No. of combinations inoculated } \\
\text { (bacterial stains } x \text { plant species) }\end{array}$ & 810 & 704 & 456 & 380 & 380 & 320 \\
\hline $\begin{array}{l}\text { No. of combinations with symptoms }{ }^{a} \\
\text { on at least } 1 \text { replicate plant }\end{array}$ & 539 & 335 & 179 & 126 & 246 & 255 \\
\hline$\%$ of the total combinations & 66.5 & 47.6 & 39.3 & 33.2 & 64.7 & 79.7 \\
\hline $\begin{array}{l}\text { No. of combinations with symptoms } \\
\text { on } \geq \text { half of the replicate plants }\end{array}$ & 336 & 170 & 169 & 105 & 181 & 217 \\
\hline $\begin{array}{l}\% \text { of the combinations with } \\
\text { symptoms on at least } 1 \text { plant }\end{array}$ & 62.3 & 50.7 & 94.4 & 83.3 & 73.6 & 85.1 \\
\hline $\begin{array}{l}\text { No. of combinations with symptoms } \\
\text { in both blocks }\end{array}$ & 258.0 & 129.0 & nd & nd & nd & nd \\
\hline $\begin{array}{l}\% \text { of the combinations with } \\
\text { symptoms on } \geq \text { half of the plants }\end{array}$ & 76.8 & 75.9 & nd & nd & nd & nd \\
\hline $\begin{array}{l}\text { No. of combinations with symptoms } \\
\text { on }>2 / 3 \text { of the replicate plants }\end{array}$ & 224 & 112 & 151 & 87 & 135 & 189 \\
\hline $\begin{array}{l}\% \text { of the combinations with symptoms } \\
\text { on at least } 1 \text { plant }\end{array}$ & 41.6 & 33.4 & 84.4 & 69.0 & 54.9 & 74.1 \\
\hline $\begin{array}{l}\text { No. of combinations with symptoms on } \\
\geq 1 \text { but }<\text { half of the replicate plants }\end{array}$ & 203 & 165 & 10 & 21 & 65 & 38 \\
\hline $\begin{array}{l}\% \text { of the combinations with symptoms } \\
\text { on at least } 1 \text { plant }\end{array}$ & 37.7 & 49.3 & 5.6 & 16.7 & 26.4 & 14.9 \\
\hline
\end{tabular}

${ }^{\mathrm{a}}$ For tests $\mathrm{A}$ and $\mathrm{B}$, plants with scores $\geq 2$ were considered to have symptoms. For test $\mathrm{C}$, herbaceous plants were considered to have symptoms if scores were $\geq 2$ and woody plants were considered to have symptoms if lesion length was $>0.1 \mathrm{~cm}$ for external symptoms and $>0.3$ for internal symptoms. For test $D$, plants were considered to have symptoms if scores were $>2$. 'nd' indicates missing data

onion, eggplant and pepper whereas in test $\mathrm{B}$ it also caused symptoms ( $\geq 3$ of the 6 replicate plants) on 7 other species for which it did not consistently cause symptoms in test A suggesting that the conditions of test $B$ were more permissive for this strain. The pathogenicity of B728A (from PG02) and of strains from PG01 (CC1544, KN10, MAFF302278, MAFF302280, USA0007), PG03 (MAFF301020, 0893_23) and PG04 (1448A, 1_6) were also evaluated in tests B and C for which five plant species were in common (sorghum, soybean, sunflower, cantaloupe and tomato). With the exception of strain 1_6, all strains had a broader host range in test $C$ than in test $B$. Overall, the mean host range of strains in PG01 and PG03 were broadest in test C. For PG02, the mean host range of strains was similar for tests A, B and C but greater for test D (Fig. 2).

\section{Host range patterns}

Host range patterns were characterized in terms of the repeatable reactions (symptoms on at least half of the replicate plants) within each test. We observed that, within each test, the strains displayed a diversity of host ranges from very restricted to very broad regardless of the gamut of phylogroups used in the test (Additional file 1: Figure S1). This diversity among strains occurred even for tests $A$ and $D$ where most of the strains within a test had been isolated from newly occurring disease epidemics on a same host (cantaloupe for test A and sugar beet for test D) (in Additional file 1: Figure S1 all strains labeled "CC" in test A were from outbreaks of cantaloupe blight in France and those labeled " $\mathrm{P}$ " in test $\mathrm{D}$ were from outbreaks of sugar beet blight in Serbia). Furthermore, there were several examples of strains that had been attributed the same pathovar denomination and were phylogenetically very close but that nevertheless had different host ranges from one another. For example, the three strains from reference collections that are called $P$. syringae pv. actinidiae (CFBP 7286, KW30 and PA459) induced symptoms on 11 to 12 different hosts but with only tomato, sunflower, kiwi and two cultivars of peach in common (Fig. 3 and Additional file 2: Table S1, test C). Likewise the two strains named pv. savastanoi (NCPPB3335 and PseNe107) both caused symptoms on cowpea, geranium, apricot and Montclar peach but strain PseNe107 caused symptoms on six additional hosts. (Fig. 3 and 
Table 2 Number of replicate plants with symptoms in different inoculation trials with strain CC0094

\begin{tabular}{|c|c|c|c|c|c|c|c|}
\hline & & $A-1998^{a}$ & B-2003 ${ }^{\mathrm{a}}$ & B-2003 & B-2003 & B-2003 & D-2017 \\
\hline Plant species & Cultivar & & trial: 1 & 2 & 3 & 4 & \\
\hline Allium cepa & Jaune Paille & 6 & 6 & 6 & 6 & 6 & 5 \\
\hline Beta vulgaris var. cicla & $\begin{array}{l}\text { Verte à carde blanche } \\
\text { sel Bressane }\end{array}$ & & & & & & 5 \\
\hline B. vulgaris var. conditiva & White Silver & & & & & & 5 \\
\hline B. vulgaris var. rapa & Ardan XS 1389 & & 6 & 6 & 6 & 6 & \\
\hline B. vulgaris var. rapa & Sucrière & 6 & & & & & 0 \\
\hline Capsicum annuum & Yolo Wonder & 6 & 6 & 6 & 6 & 6 & 5 \\
\hline Cucumis melo var. cantalupensis & Védrantais & 11 & 6 & 6 & 6 & 6 & 4 \\
\hline C. sativus & Marketer & 3 & 5 & 6 & 6 & 6 & 4 \\
\hline Glycine max & Paoki & 2 & 6 & 5 & 5 & 4 & \\
\hline Helianthus annuus & Dogo & 5 & 6 & 6 & 6 & 6 & \\
\hline Hordeum vulgare & Baronesse & 1 & 3 & 6 & 4 & 5 & \\
\hline Lactuca sativa & Mantila & 3 & 6 & 6 & 6 & 6 & 5 \\
\hline Phaseolus vulgaris & Canadian Wonder & 5 & 6 & 6 & 6 & 3 & \\
\hline Pisum sativum & Douce Provence & 6 & 6 & 6 & 6 & 6 & 3 \\
\hline Solanum lycopersicum & Monalbo & 5 & 5 & 4 & 4 & 2 & 5 \\
\hline S. melongena & Violette & 4 & 2 & 5 & 2 & 4 & \\
\hline Sorghum bicolor & Argence & 0 & 6 & 5 & 3 & 3 & \\
\hline Triticum aestivum & Vic & & 3 & 6 & 6 & 6 & \\
\hline T. aestivum & Soisson & 0 & & & & & \\
\hline Zea mays L. & Epi d'Or & 3 & 3 & 6 & 3 & 6 & \\
\hline
\end{tabular}

${ }^{\mathrm{a}}$ For tests $\mathrm{A}$ and $\mathrm{B}, 6$ replicate plants of each species were inoculated, except for tomato and cantaloupe in test A where 5 and 11 replicates were inoculated. Plants were considered to have symptoms if the disease score was $\geq 2$. Four independent trials with CC0094 were conducted for test B. ${ }^{b}$ For test $D, 5$ replicate plants of each species were inoculated. Plants were considered to have symptoms if the disease score was $\geq 3$

Additional file 2: Table S1, test C). The two strains named pv. aptata (CFBP1617 and CFBP1906) also had different host ranges, with eight hosts in common in addition to sugar beet but with six additional hosts for CFBP1906 (Additional file 2: Table S1, test A).

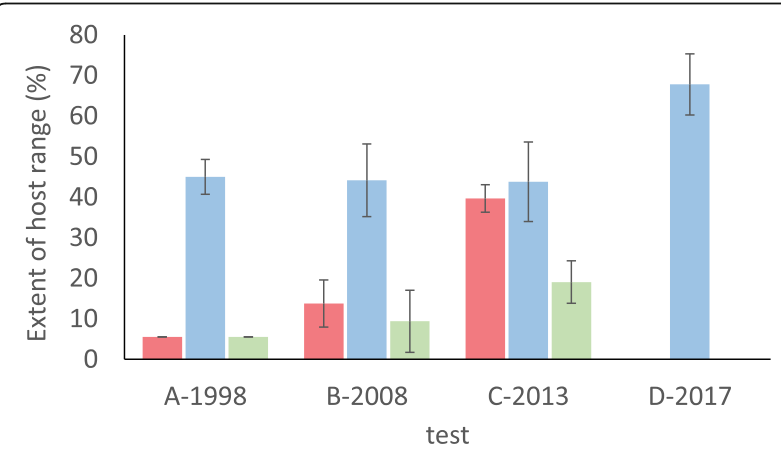

Fig. 2 Extent of host range of phylogroups 1 (red), 2 (blue) and 3 (green) of $P$. syringae, expressed as the percent of plant species for which at least half of the inoculated replicate plants manifest symptoms in each of four independent tests. Error bars indicate standard error of mean percents
In none of the tests the host range showed patterns that revealed groups of strains with distinct, well-defined host ranges. Strikingly, in all tests, host ranges were overlapping and could be arranged into patterns that appeared nested (Fig. 3 for test C, Additional file 1: Figure S1 for the others). The three statistics for nestedness (overlapping host ranges) and the four statistics for modularity (distinguishable groups with defined host ranges) calculated here showed that the host range patterns in all four tests were significantly nested and showed no detectable modules (Table 3). For test $\mathrm{C}$ we assessed the effect of different thresholds of regularity and intensity of symptom expression on the host range pattern for all plant species considered together and for herbaceous and woody species considered independently (Table 3 ). None of the different thresholds resulted in significant modularity and all resulted in significant nestedness of host range patterns.

\section{Relationship between the extent of host range, phylogeny, general genomic features and motility}

The outcomes of host range tests conducted under laboratory conditions are contingent on numerous factors that can modulate the success of microorganisms in 


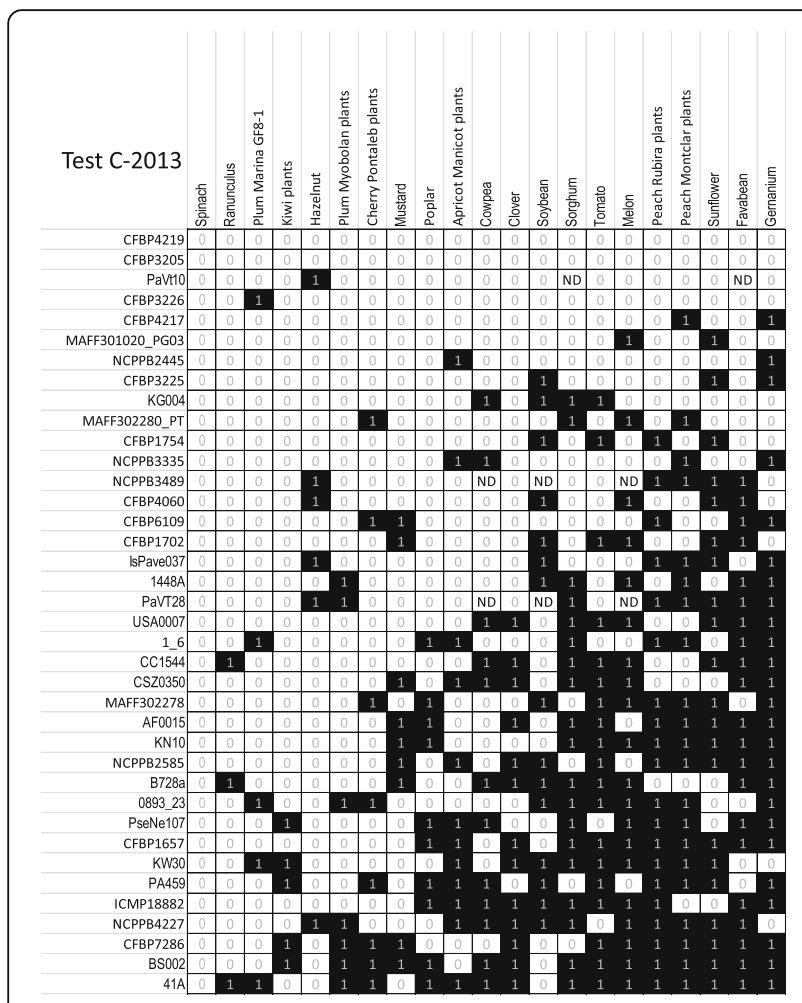

Fig. 3 Host range of strains evaluated in test C. Black boxes correspond to plant-strain interactions where at least 3 of the 4 inoculated replicate herbaceous plants had disease scores $>1$ and at least 3 of the 4 inoculated woody plants had external lesions longer than $0.1 \mathrm{~cm}$. Strains are arranged in terms of increasing number of hosts and plant species are arranged in terms of increasing number of virulent strains. ND indicates missing data

invading plant tissue and the ability of the plants to elicit their defenses. These modulating factors might be different in the laboratory compared to those under field conditions thereby leading to debate about the value of laboratory tests for assessing virulence of a microorganism on a given plant species-especially if disease on this species has not already been observed under field conditions. In light of this concern, we searched for traits of $P$. syringae that could bolster the pertinence of our laboratory host range tests as an indicator of the potential of $P$. syringae.

To summarize the host range of strains into a parameter comparable across all tests we calculated the extent of the host range. This could be calculated for all strains within a test and did not rely on having common plant species among tests. Host range extent was expressed as the percent of plant species on which each strain was virulent within a test. As described above, a strain was considered virulent on a given plant species if at least half of the replicate plants tested showed symptoms. For strains that were evaluated in more than one test, the mean percent was calculated.
Among all 134 strains of $P$. syringae, representing eight phylogroups, the extent of host range ranged from 0 to $100 \%$. This range was variable within phylogroups, but only PG02 contained strains that were virulent on more than $75 \%$ of the plant species tested (Fig. 4). An analysis of variance ( 1 factor) indicated that there was a significant effect of phylogroup on the extent of host range $(P<0.000)$. In pairwise comparisons, strains in PG02 had a significantly greater mean extent of host range compared to those in PG01 and PG03 (Tukey's Honest Significant Difference Test, $P \leq 0.02$ ) (Fig. 5). The variability among strains and the low number of strains tested for the other phylogroups did not facilitate statistical comparisons for these groups.

The extent of host range was compared to the capacity of strains to swarm in amoeboid, star-like patterns on semi-solid nutrient medium. Swarming was evaluated for 51 strains from PG01, PG02, PG03 and PG04 that were selected to represent closely related strains with contrasting host ranges (Additional file 2: Table S1). About $70 \%$ of the strains that consistently displayed swarming within $27 \mathrm{~h}$ after inoculation on soft-agar medium were virulent on at least half of the plant species tested whereas over $80 \%$ of the strains that did not swarm by $48 \mathrm{~h}$ were virulent on fewer than half of the plant species tested (Fig. 6). To assess the statistical significance of the interaction between motility and host range, we compared the frequencies of strains that caused disease to i) more than $60 \%$ or ii) less than $25 \%$ of the plant species tested coupled to whether or not they consistently swarmed. There were sufficient strains to test the interaction of motility and host range for all strains combined and for strains in PG02 apart from the others. Contingency tests showed that there was a significant association $(P<0.01)$ of swarming motility with broad host range ( $>60 \%$ of plant species) and of lack of motility with narrow host range $(<25 \%$ of plant species) for PG02 and for all strains considered together (Table 4).

The correlation of each of 13 genomic features provided on the JGI platform (see Methods) with the extent of host range was assessed with Spearman's Rank Correlation test. Only two of these features showed significant correlations $(P<0.05)$. For all strains considered together, the extent of host range had a significant negative correlation with the number of genes for transmembrane domains (correlation coefficient $=-0.330$ ) and a positive correlation with the number of genes in biosynthetic clusters (correlation coefficient $=0.313)($ Fig. 7$)$.

\section{Discussion}

Our results strongly suggest that the individual strains in the $P$. syringae complex constitute an overlapping continuum of potential host ranges with roughly equal 
Table 3 Estimation and statistical significance of nestedness and modularity in the Pseudomonas syringae-plant symptomatology matrices

\begin{tabular}{|c|c|c|c|c|c|c|c|c|c|c|c|c|}
\hline & & & & \multicolumn{9}{|c|}{ Tests for nestedness } \\
\hline Test & Plants & $\begin{array}{c}\text { Type of } \\
\text { symptoms } \\
\text { on woody } \\
\text { plants }\end{array}$ & Disease score groups ${ }^{\mathrm{a}}$ & 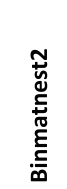 & 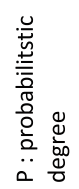 & 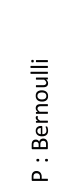 & $\begin{array}{l}\text { N } \\
\text { 을 }\end{array}$ & 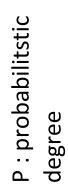 & 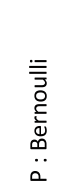 & $\frac{\mathscr{2}}{3}$ & 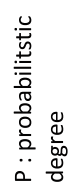 & 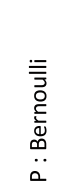 \\
\hline A-1998 & Herbaceous & - & $0-1$ vs. 2-3 & $12.8^{\mathrm{b}}$ & $0.000^{c}$ & 0.000 & 77.0 & 0.000 & 0.000 & 0.63 & 0.000 & 0.000 \\
\hline B-2008 & Herbaceous & - & $0-1$ vs. $2-3$ & 18.8 & 0.000 & 0.000 & 65.7 & 0.000 & 0.000 & 0.54 & 0.000 & 0.000 \\
\hline C-2013 & Woody + herbaceous & External & 0 vs. $1-8$ ( $\geq 0.1$ for woody) & 26.5 & 0.000 & 0.000 & 59.9 & 0.000 & 0.000 & 0.35 & 0.000 & 0.000 \\
\hline C-2013 & Woody + herbaceous & External & $\begin{array}{l}0-1 \text { vs. } 2-8 \text { herbaceous, } \\
\geq 0.3 \text { woody }\end{array}$ & 20.6 & 0.000 & 0.000 & 56.5 & 0.000 & 0.000 & 0.46 & 0.000 & 0.000 \\
\hline C-2013 & Woody + herbaceous & Internal & 0 vs. $1-8$ ( $\geq 0.3$ for woody) & 24.1 & 0.000 & 0.000 & 73.0 & 0.000 & 0.000 & 0.51 & 0.000 & 0.000 \\
\hline C-2013 & Woody + herbaceous & Internal & $\begin{array}{l}0-1 \text { vs. } 2-8 \text { herbaceous, } \\
\geq 0.3 \text { woody }\end{array}$ & 21.6 & 0.000 & 0.000 & 68.8 & 0.000 & 0.000 & 0.52 & 0.000 & 0.000 \\
\hline$C-2013$ & Herbaceous alone & - & 0 vs. 1-8 & 23.1 & 0.000 & 0.000 & 62.2 & 0.000 & 0.000 & 0.48 & 0.000 & 0.000 \\
\hline C-2013 & Herbaceous alone & - & $0-1$ vs. $2-8$ & 25.2 & 0.000 & 0.000 & 61.7 & 0.000 & 0.000 & 0.44 & 0.000 & 0.000 \\
\hline C-2013 & Woody alone & External & $0 v s . \geq 0.1$ & 28.3 & 0.018 & 0.000 & 50.2 & 0.007 & 0.000 & 0.31 & 0.003 & 0.001 \\
\hline C-2013 & Woody alone & External & $0 v s . \geq 0.3$ & 22.2 & 0.100 & 0.001 & 47.0 & 0.003 & 0.000 & 0.47 & 0.001 & 0.000 \\
\hline$C-2013$ & Woody alone & Internal & 0 vs. $\geq 0.1$ & 16.4 & 0.000 & 0.000 & 73.3 & 0.000 & 0.000 & 0.54 & 0.000 & 0.000 \\
\hline C-2013 & Woody alone & Internal & 0 vs. $\geq 0.3$ & 20.1 & 0.000 & 0.000 & 71.0 & 0.000 & 0.000 & 0.58 & 0.000 & 0.000 \\
\hline D-2017 & Herbaceous & - & $0-1$ vs. 2-3 & 4.1 & 0.000 & 0.000 & 86.8 & 0.000 & 0.000 & 0.89 & 0.000 & 0.000 \\
\hline
\end{tabular}

\begin{tabular}{|c|c|c|c|c|c|c|c|c|c|c|c|c|c|c|c|}
\hline \multirow[b]{2}{*}{ Test } & \multirow[b]{2}{*}{ Plants } & \multirow[b]{2}{*}{$\begin{array}{c}\text { Type of } \\
\text { symptoms } \\
\text { on woody } \\
\text { plants }\end{array}$} & \multirow[b]{2}{*}{$\begin{array}{l}\text { Disease score } \\
\text { groups }\end{array}$} & \multicolumn{12}{|c|}{ Tests for modularity } \\
\hline & & & & 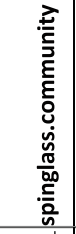 & 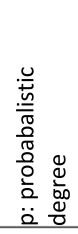 & 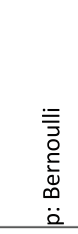 & 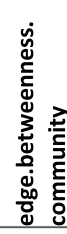 & 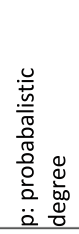 & 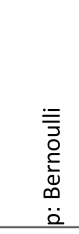 & 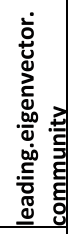 & 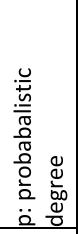 & 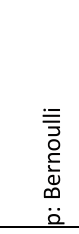 & 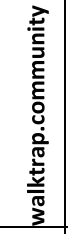 & 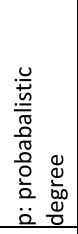 & 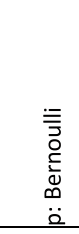 \\
\hline A-1998 & Herbaceous & - & $0-1$ vs. $2-3$ & $0.14^{b}$ & 0.930 & 1.000 & 0.00 & 0.761 & 0.875 & 0.12 & 0.670 & 0.970 & 0.01 & $N A$ & 0.330 \\
\hline B-2008 & Herbaceous & - & $0-1$ vs. $2-3$ & 0.16 & 0.600 & 1.000 & 0.01 & 0.813 & 0.821 & 0.18 & 0.210 & 0.828 & 0.01 & 0.230 & 0.564 \\
\hline C-2013 & $\begin{array}{l}\text { Woody + } \\
\text { herbaceous }\end{array}$ & External & $\begin{array}{l}0 \text { vs. } 1-8 \text { ( } \geq 0.1 \text { for } \\
\text { woody) }\end{array}$ & 0.15 & 1.000 & 1.000 & 0.00 & 0.960 & 0.780 & 0.14 & 1.000 & 1.000 & 0.00 & 0.980 & 1.000 \\
\hline C-2013 & $\begin{array}{l}\text { Woody }+ \\
\text { herbaceous }\end{array}$ & External & $\begin{array}{l}0-1 \text { vs. } 2-8 \\
\text { herbaceous, } \geq 0.3 \\
\text { woody }\end{array}$ & 0.18 & 0.670 & 0.540 & 0.02 & 0.760 & 0.560 & 0.20 & 0.900 & 0.720 & 0.01 & 0.740 & 0.450 \\
\hline C-2013 & $\begin{array}{l}\text { Woody + } \\
\text { herbaceous }\end{array}$ & Internal & $\begin{array}{l}0 \text { vs. } 1-8 \text { ( } \geq 0.3 \text { for } \\
\text { woody) }\end{array}$ & 0.14 & 0.580 & 0.550 & 0.00 & 1.000 & 1.000 & 0.11 & 1.000 & 1.000 & 0.00 & $N A$ & $N A$ \\
\hline C-2013 & $\begin{array}{l}\text { Woody + } \\
\text { herbaceous }\end{array}$ & Internal & $\begin{array}{l}0-1 \text { vs. 2-8 } \\
\text { herbaceous, } \geq 0.3 \\
\text { woody }\end{array}$ & 0.13 & 0.990 & 1.000 & 0.00 & 1.000 & 1.000 & 0.11 & 1.000 & 1.000 & 0.00 & 1.000 & $N A$ \\
\hline C-2013 & $\begin{array}{l}\text { Herbaceous } \\
\text { alone }\end{array}$ & - & 0 vs. 1-8 & 0.00 & 1.000 & 1.000 & 0.00 & 1.000 & 1.000 & 0.17 & 0.720 & 0.495 & 0.01 & 0.766 & 0.364 \\
\hline C-2013 & $\begin{array}{l}\text { Herbaceous } \\
\text { alone }\end{array}$ & - & $0-1$ vs. 2-8 & 0.17 & 0.890 & 0.860 & 0.00 & 1.000 & 1.000 & 0.17 & 0.700 & 0.870 & 0.02 & 0.650 & 0.470 \\
\hline C-2013 & Woody alone & External & 0 vs. $\geq 0.1$ & 0.00 & 1.000 & 1.000 & 0.01 & 0.926 & 0.977 & 0.24 & 0.620 & 0.470 & 0.06 & 0.910 & 0.977 \\
\hline C-2013 & Woody alone & External & 0 vs. $\geq 0.3$ & 0.20 & 0.960 & 1.000 & 0.25 & 0.374 & 0.220 & 0.23 & 0.930 & 1.000 & 0.19 & 0.780 & 1.000 \\
\hline C-2013 & Woody alone & Internal & 0 vs. $\geq 0.1$ & 0.14 & 0.890 & 0.980 & 0.00 & 1.000 & 1.000 & 0.09 & 0.980 & 0.950 & 0.00 & 1.000 & $N A$ \\
\hline C-2013 & Woody alone & Internal & 0 vs. $\geq 0.3$ & 0.15 & 0.890 & 0.960 & 0.00 & 1.000 & 1.000 & 0.13 & 0.970 & 0.967 & 0.01 & 0.690 & 0.500 \\
\hline D-2017 & Herbaceous & - & $0-1$ vs. $2-3$ & 0.12 & 1.000 & 1.000 & 0.00 & 1.000 & 1.000 & 0.07 & 0.710 & 0.990 & 0.00 & $N A$ & $N A$ \\
\hline
\end{tabular}

'Disease scores, as described in the Methods section, were combined into two groups reflecting different thresholds for disease category "0" (no symptoms, no virulence) vs. disease category " 1 " (sensitive host, virulent pathogen). "Values of nestedness or modularity for the actual pathogenicity matrix. Estimated values were rescaled in order that minimum and maximum were 0 and 100, respectively. Statistical significance is indicated between parentheses as the numbers of simulations (over 1000 for nestedness and over 100 for modularity) under the probabilistic degree (first figure) and Bernoulli (second figure) null models showing higher values than the actual pathogenicity matrix. All tests for nestedness were significant under the Bernoulli null model and in all but one case for the probabilistic degree model. Only one test out of 40 showed significant modularity. In some cases (indicated NA) the algorithm was not applicable to calculating modularity because the level of modularity was too low. 'Probabilities highlighted in black indicate tests that are significant at $P<0.05$ 
representation of those with narrow, intermediate and broad host ranges. This result is consistent with the current view that the mechanisms leading to disease involve multiple factors of virulence and fitness of the pathogen and of a corresponding multiplicity of host defenses that are all modulated by environmental factors. For $P$. syringae, virulence involves an interplay of extracellular outer membrane structures (such as MAMPs (Newman et al. 2013)) that can set off generic, nonhost defenses in the plant; of multiple effectors that can elicit and/or disarm host defenses more or less specifically and that target a wide range of plant cell functions; and toxins that can have either specific or a wide range of targets (Pfeilmeier et al. 2016; Xin et al. 2018). During the process of inciting disease, growth of bacteria in plant tissue depends on expression of genes for traits that assure tolerance of osmotic conditions in the apoplast and the metabolism of $\gamma$-aminobutyric acid as its availability in the apoplast increases (Pfeilmeier et al. 2016). All of these processes, as well as those involved in plant responses to infection, are highly dependent on environmental conditions, with temperature, water availability and soil nutrients in particular having marked effects (Dordas 2008; Velásquez et al. 2018) and being among the most pertinent to the outcome of laboratory tests of pathogenicity. These environmental factors influence the outcome of the host-pathogen interaction via their effects on, for example, the effectiveness of PAMP-triggered immunity, the regulation of defense hormones, the expression of proteins involved in effector-triggered immunity of the plant, the expression of phytotoxins and regulation of the type 3 secretion system by bacteria (Velásquez et al. 2018). Given the complex processes involved in disease causation and in light of the results of our experimental inoculations, we propose that strains of $P$. syringae have general tendencies of host range potential, but that the outcome of the molecular interaction with the plant-in terms of symptom expression-is highly contingent on the biotic and abiotic context. Although this contingency on the environment is

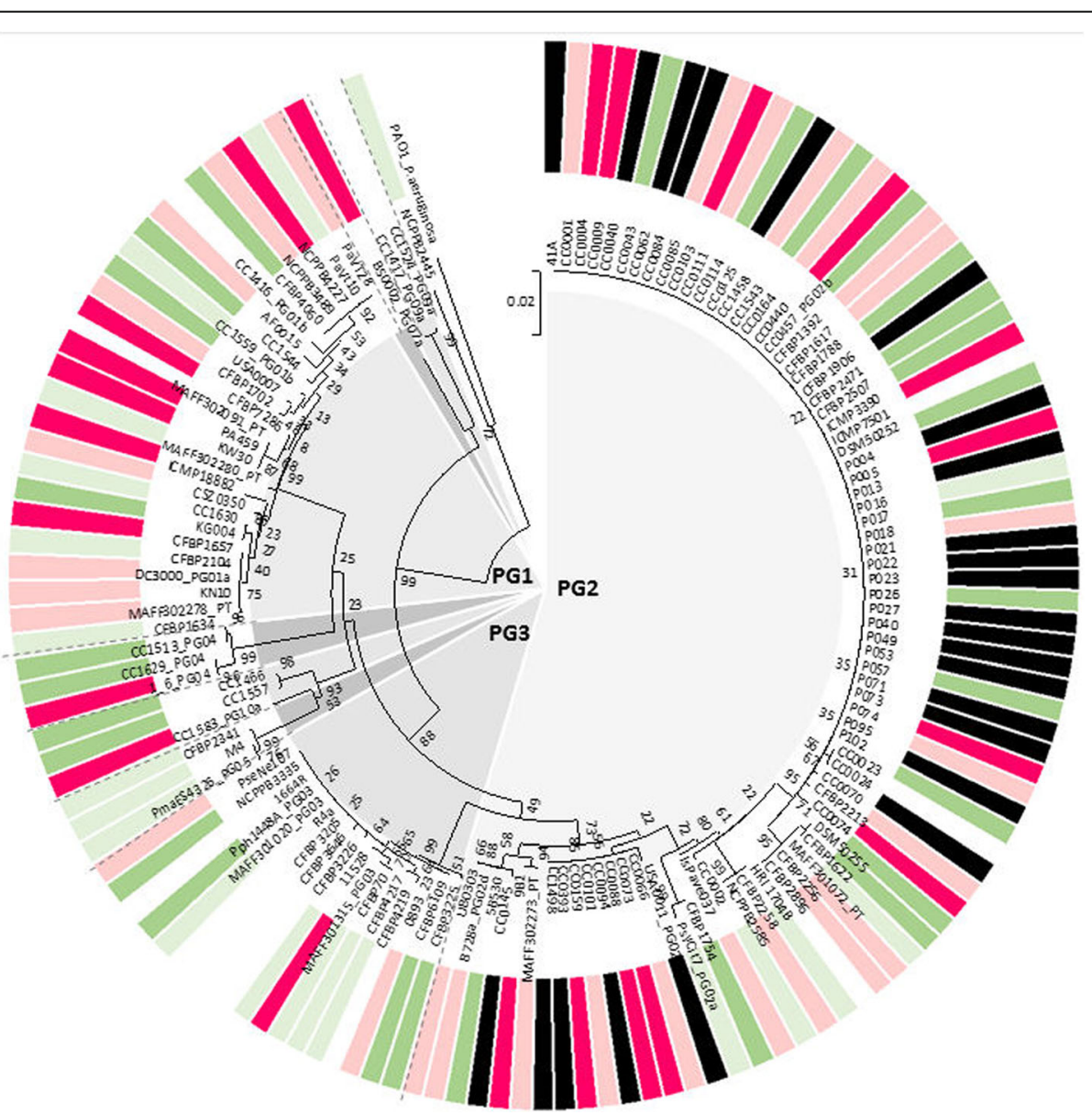

Fig. 4 Phylogenetic tree of 134 strains of Pseudomonas syringae from eight phylogroups and of $P$. corrugata for which virulence was evaluated on 16 to 22 plant species. The extent of the host range of each strain is indicated in the outer colored circle (virulent on $>75 \%$ of plant species tested: black; > 50\% to 75\%: red; > 25\% to 50\%: pink; > 10\% to 25\%: dark green; > 0 to 10\%: light green; 0: white). Strains were considered to be virulent on a plant species if they caused symptoms on at least half of the replicate plants in each test. The neighbor-joining phylogenetic tree was constructed based on partial sequences of the citrate synthase housekeeping gene as previously described (Berge et al. 2014) 


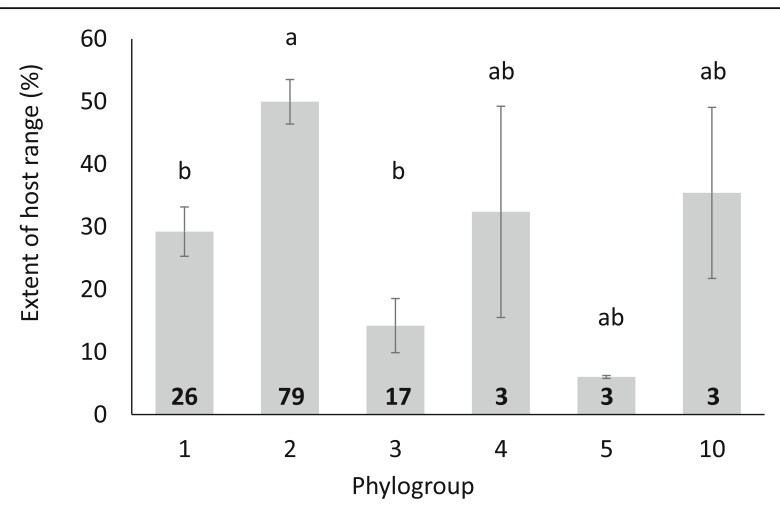

Fig. 5 Extent of host range of the strains in different phylogroups of Pseudomonas syringae. Host range is expressed as the mean of the percent of plant species in each test on which strains in a given phylogroup were virulent (caused symptoms on at least half of the replicate plants). The number of strains tested in each phylogroup is indicated in boldface. Only phylogroups for which more than 2 strains were tested are presented here. Error bars represent standard error of the means. Means associated with the same lower case letter are not significantly different based on pair-wise comparisons (Tukey's Honest Significant Difference Test, $P<0.05$ )

a well-accepted phenomenon, it implies that it is very difficult to define the precise host range of strains of $P$. syringae-in terms of a list of plants on which it can cause disease-without conducting multifactorial experiments that account for the effect of environment on the many interacting factors involved in disease manifestation. On the other hand, our results suggest that the potential breadth of the host range, relative to that of other strains, can be estimated.

The breadth of host range that we observed was consistent with other traits that have been reported to be well correlated with pathogenic potential-such as motility, the function of certain transmembrane proteins and the products of biosynthetic clusters. Swarming motility has been shown to be an important means for plant associated bacteria to assure invasion of plant tissue and to move to new nutritional reservoirs (summarized in

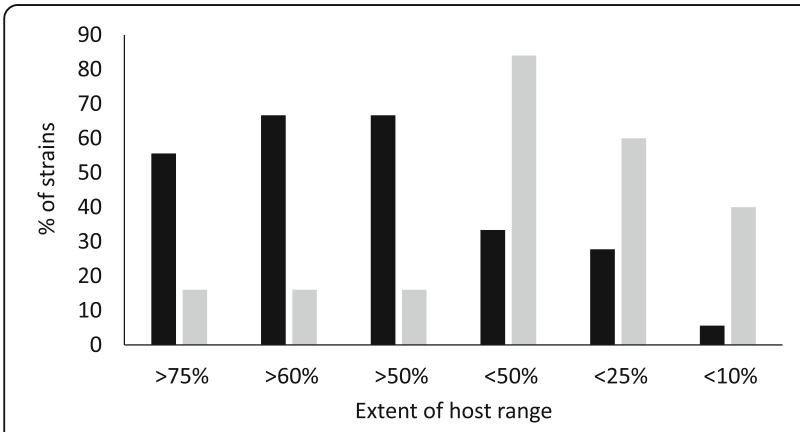

Fig. 6 The extent of host range in strains of Pseudomonas syringae that displayed swarming by $27 \mathrm{~h}$ on a nutrient medium (black bars) compared to those that did not display swarming by $48 \mathrm{~h}$ (grey bars)
(Venieraki et al. 2016)) and to be positively correlated with pathogenicity in individual strains as revealed by mutants that are altered in their ability to swarm (Ichinose et al. 2016; Cheng et al. 2017). This is consistent with our observation that strains with the broadest host range tend to be those that swarm, and conversely those that do not swarm tend to have narrower host ranges. Concerning transmembrane domains, in the strains used here there was a wide range of genes that were characterized as coding for transmembrane proteins (1062 to 1565 such genes per strain) and included efflux pumps, various transporters, Type 3 Secretion System components, pili and fimbriae components, and cold shock proteins among others. These could constitute some of the known PAMPs that stimulate host defenses (Ingle et al. 2006) and therefore the accumulation of such factors could interfere with virulence. This is consistent with the negative correlation between the extent of host range and the number of genes for transmembrane proteins that we observed. Biosynthetic clusters refer to genes for polyketides, non-ribosomal peptides, terpenoids, alkaloids and other ribosomally-synthesized and post-translationally modified peptides, as well as saccharides (Medema et al. 2015). Many of the molecules synthesized in these pathways have biocidal activity against prokaryotic and/or eukaryotic cells (Arnison et al. 2013) and therefore the accumulation of such traits could overcome host defenses and also increase the aggressiveness of strains. This is consistent with the positive correlation that we observed between host range extent and the number of genes in biosynthetic clusters.

What are the implications of these results? Firstly, they have consequences for how to anticipate and protect plants from new disease epidemics caused by $P$. syringae. Indeed, among the vast diversity of strains (clonal lines) of $P$. syringae that inhabit Earth, relatively few have been captured in the act of causing disease to plants. The relatively few strains that have caused epidemics have succeeded, in part, because they have traits that allow them to proliferate in plant tissue and also because of a concurrence of circumstances that fostered i) their contact with plants, ii) the expression of the traits that allow them to proliferate in plants and iii) the inhibition of plant defense mechanisms. Over time there will be new opportunities for strains in the environment that have not already been responsible for epidemics to come into contact with crops. Changes in the climate and in the global environment will likely also increase opportunities for pathogens such as $P$. syringae to cause disease (Velásquez et al. 2018). Protecting plants from disease involves a combination of a rapid response to the appearance of disease symptoms and the avoidance of risky situations. In light of ever-changing environmental contexts, of the wide-spread dissemination of $P$. syringae 
Table 4 The number of strains of Pseudomonas syringae in phylogroup 2 and for all phylogroups considered together according to their host range extent and capacity to swarm on semi-solid nutrient medium. In both cases, there is a significant interaction of host range extent and swarming (Fisher's exact test, $P<0.01$ ). There were not sufficient strains to test the interaction of swarming and host range for phylogroups other than PG02

\begin{tabular}{lll}
\hline PG02 & Swarming at $27 \mathrm{~h}$ & No swarming at $48 \mathrm{~h}$ \\
Extent of host range $>60 \%$ & 10 & 4 \\
Extent of host range $<25 \%$ & 1 & 8 \\
All phylogroups & 12 & 4 \\
Extent of host range $>60 \%$ & 4 & 15 \\
Extent of host range $<25 \%$ & 4 \\
\hline
\end{tabular}

within agriculture and among all the various habitats of this bacterium, and of the vast diversity of this bacterial group (Berge et al. 2014) the main challenge is to identify and survey for risky situations that can set crops into contact with reservoirs of $P$. syringae under conditions favorable for disease. Avoiding risky situations involves

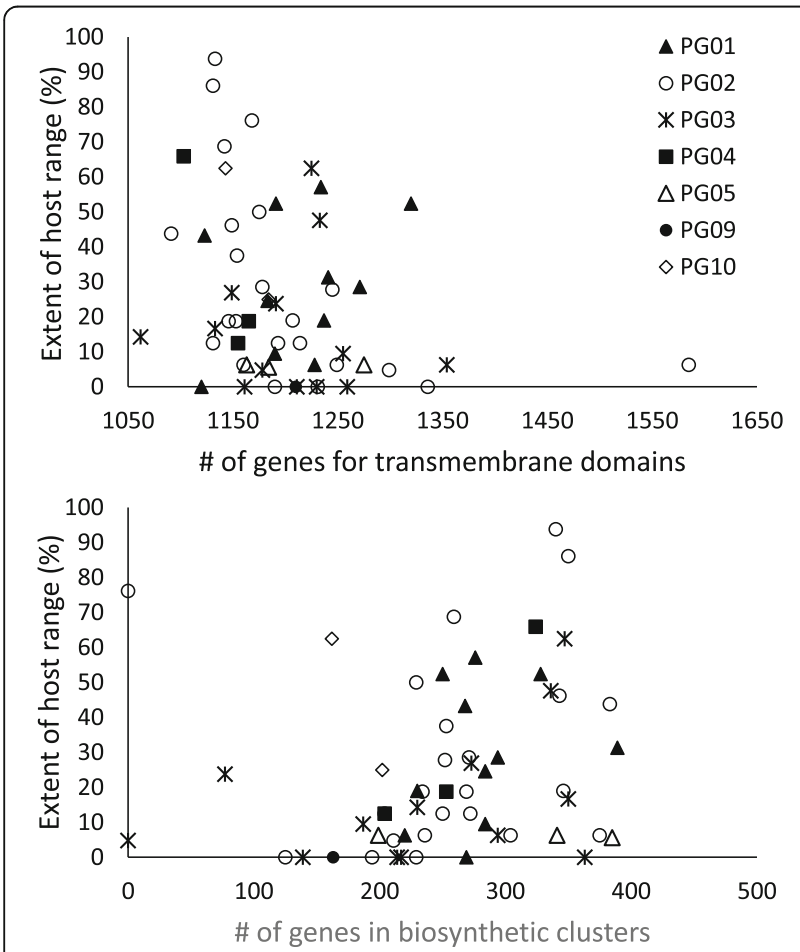

Fig. 7 The extent of host range of 56 strains of Pseudomonas syringae, for which whole genome sequences are available, as a function of genomic features annotated by the Joint Genome Institute Integrated Microbial Genomes and Microbiome System (https://img.jgi.doe.gov). The phylogroup (PG) of each strain is indicated for the seven phylogroups represented by this set of strains. The genomic traits presented here are those for which there were statistically significant $(P<0.05)$ correlations, based on Spearman's Rank Order Correlation. For all strains considered together, the extent of host range is significantly correlated with the number of genes for transmembrane domains (correlation coefficient $=-0.330$ ) and the number of genes in biosynthetic clusters (correlation coefficient $=0.313$ ) knowing the conditions that favor disease as well as surveying for early detection of the pathogen. It is increasingly easy to deploy biotechnological tools to survey cropping systems, their frontiers and inputs for risky microorganisms before they cause disease symptoms. Our results suggest that surveying for strains of $P$. syringae that could cause new diseases would involve identifying the factors that underlie broad host range. This approach would be distinct from and complementary to the diagnostics used to target the lines of the bacterium that are known to have already caused disease to specific crops. In addition, our results have implications for how breeders select plants for resistance to diseases caused by $P$. syringae in terms of the traits and origin of strains to use in screening.

A second consequence of these results concerns how we perceive pathotypes of $P$. syringae. Our results provide strong evidence that strains do not cluster into groups with similar and distinct host ranges under comparable experimental conditions. This lack of groupings was observed for strains from diverse sources (tests B and $C$ ) as well as for strains that were mainly from epidemics on a single host species (cantaloupe for test A and sugar beet for test $C$ ). These results are difficult to reconcile with the pathovar nomenclature that specifies that strains should have "distinctive pathogenicity to one or more plant hosts" and that they are usually "distinguished in terms of proved differences in host range" (Young et al. 2001). According to these characteristics of pathovars, one could argue that nearly every strain among those characterized here is in a distinct pathovar-including strains that currently have the same pathovar names such as pv. actinidiae, pv. savastanoi, or pv. aptata. As far as we are aware, the data presented here represent the most comprehensive effort to assess differences in host range, including reports that describe pathovars. Our observations suggest that current pathovar names do not necessarily take into account the full potential of strains. Furthermore, in view of the overlapping continuum of pathogenicity under comparable conditions and the lack of pathotypes that can be distinguished from one another, we suggest that the 
concept of pathovar as currently defined is inappropriate for $P$. syringae and is misleading.

At present, "pathovars" constitute an important vocabulary for diagnostics and quarantine. Therefore, we expect considerable opposition to proposals to eliminate this vocabulary for $P$. syringae. However, the obstacles to changing the vocabulary for $P$. syringae can be overcome. As pointed out previously, although pathovars are named in legislation to control the emergence and movement of various strains of phytopathogenic bacteria, in reality the directives are implemented in the form of standard diagnostic procedures that correspond to approved techniques (Morris et al. 2017). Clear description of the techniques and their proper implementation-and not a description of the pathovar-are what assure the efficacy of quarantine and the accuracy of the diagnostics. Furthermore, there is growing recognition that the various clades in the P. syringae complex (Berge et al. 2014) can be grouped into separate species based on genetic similarities and the naming of new species within the complex (such as $P$. amygdali) in addition to $P$. viridiflava is increasing (Gomila et al. 2017). The work of Gomila and colleagues (Gomila et al. 2017) on the phylogenetic groupings across the $P$. syringae complex illustrates that new species designations will bring together strains that currently have different pathovar names and will distribute other strains with the same pathovar names across several species. This will lead to important confusion if pathovar naming according to current practices is maintained.

The concept that pathogenicity of $P$. syringae is structured in distinct groups ignores the complex factors involved in the manifestation of symptoms including the vagaries of the physical environment and possible synergies with other plant microflora. This concept can be a barrier to understanding the etiology, epidemiology and emergence of diseases. It also constrains how detection, diagnostics and breeding for disease resistance are conceived and implemented. A more robust concept of host range that accounts for the continuum of pathogenic behaviors in P. syringae would be an impetus to search for novel markers of pathogenicity that could be deployed for risk assessment. It could also incite breeders to take new approaches to screening for disease resistance by establishing collections of challenge strains that represent this continuum and thereby are likely to also represent a diversity of virulence mechanisms or the fine-tuning of their regulation.

\section{Conclusions}

We present a comprehensive effort to assess differences in host range among strains of $P$. syringae to address the questions of the breadth of its host range and how pathotypes are structured. In four independent tests our results show that host range in the $P$. syringae complex is an overlapping continuum of potential with strains that have narrow host ranges being just as frequent as those with moderate and those with broad host ranges. These results are consistent with the current paradigm that manifestation of disease symptoms is the result of multiple molecular interactions between $P$. syringae and its plant host that are modulated by abiotic and biotic conditions. We argue that these results strongly support the need to move beyond the concept that $P$. syringae is composed of discrete, discernable pathovars and it opens the door to explore new scenarios of evolution of pathogenicity, of disease emergence and of the means to manage plant diseases caused by this bacterium.

\section{Methods}

\section{Bacterial strains}

We assessed the pathogenic potential of 134 strains from phylogroups (PG) 1, 2, 3, 4, 5, 7, 9 and 10. Reference strains for the $P$. syringae complex isolated from diseased plants were sourced from public collections or kindly provided by others. A strain of $P$. corrugata from tomato was also included. The origin of all strains used in this study is described in Additional file 2: Table S1. For strains in the inoculation test $\mathrm{C}$ described below, molecular fingerprints were determined for all strains by BOX-PCR as described previously (Versalovic et al. 1991) to allow traceability in host range testing. All strains were stored in $40 \%$ glycerol at $-80^{\circ} \mathrm{C}$. Strain CC0094 was used as a common strain in all tests except $\mathrm{C}$ so that variability or results could be compared. This strain was isolated from a cantaloupe blight epidemic in France, represents a clonal line that has been found in both epidemics and environmental reservoirs (Monteil et al. 2016) and has been used as a reference strain in our laboratory for over 20 years.

To determine the relative phylogenetic context of all of the strains, Neighbor-joining phylogenetic trees were constructed on the basis of partial sequences of the citrate synthase housekeeping gene (cts) as previously described (Berge et al. 2014). The forward and reverse primers for amplification and the primers for sequencing were, respectively, Cts-FP (forward): 5'-AGTTGATCA TCGAGGGCGC(AT)GCC-3', Cts-RP (reverse): 5'-TGA TCGGTTTGATCTCGCACGG-3' and Cts-FS (fwd): 5'-CCCGTCGAGCTGCCAAT(AT)TTGCTGA-3' as used previously (Stopelli et al. 2017). DAMBE (version 5.6.8) was used for aligning sequences and Neighborjoining trees were built with Mega (version 5.05). Reference strains used to build the trees and not used for inoculations of plants were described elsewhere (Berge et al. 2014).

Genomic data for 56 of the strains tested here (indicated in Additional file 2: Table S1) were available from 
the Joint Genomic Institute (JGI) Integrated Microbial Genomes and Microbiome System (https://img.jgi.doe.gov/). The variables obtained were as follows: genome size, gene count, CRISPR count, coding base count, CDS count, RNA count, tRNA count, pseudogene count, fused gene count, signal peptide count, transmembrane domain count, horizontally-transferred gene count, and biosynthetic cluster gene count.

\section{Plant material and cultivation}

Collectively across all tests, 40 species of plants were used for pathogenicity tests (Table 5). Plants were grown and maintained in the greenhouse. All annual plants tested were seed-grown and transplanted in fresh medium-decomposed white sphagnum peat. Prunus spp. plants were sourced from commercial nurseries producing plants from seed, re-potted in the same substrate and maintained in a glasshouse at ambient temperature until inoculation. The rest of the woody plants, (hazelnut, kiwifruit, oleander and poplar) were vegetatively propagated, re-potted in the same substrate and maintained in the same conditions. All perennial plant materials used were certified. Annual plants were inoculated one month after sowing (3 to 5 true leaves) while 2-year-old Prunus spp. and 3-month-old hazelnut, kiwifruit, oleander and poplar plants were used for the inoculation.

\section{Host range tests}

Four separate host range tests were conducted. Test A was conducted in 1998 to characterize strains from a new epidemic of bacterial canker of cantaloupe that was emerging in France. Test B was conducted in 2008 to compare reference strains to strains from environmental reservoirs. Test $\mathrm{C}$ was conducted in 2013 to compare strains from woody hosts with reference strains and strains from environmental reservoirs. Test D was conducted in 2017 to characterize strains from a new epidemic of bacterial blight of sugar beet that was emerging in Serbia. Results for some of the strains in test A were described previously (Morris et al. 2000) but none of the results from the other tests have been reported previously.

Tests A and B were each conducted in 2 separate blocks with 3 plants per species for each bacterial strain per block. Tests $\mathrm{C}$ and $\mathrm{D}$ were each conducted in 1 block with 4 and 5 plants per species, respectively, for each bacterial strain. Plants were inoculated with 10$50 \mu \mathrm{L}$ of bacterial suspension, prepared in sterile distilled water from $48 \mathrm{~h}$ cultures on King's medium B (King et al. 1954) and adjusted to about $10^{8} \mathrm{CFU} / \mathrm{mL}$ depending on the test. This concentration of inoculum is among the most frequently used in host range testing of $P$. syringae and well within the range of conditions commonly used to test the pathogenicity of $P$. syringae (Additional file 3: Table S2). Plants were incubated in greenhouses and scored for up to 6-15 days for herbaceous plants and up to 60 days for woody plants depending on the test. The specific conditions and the scoring methods used for each test are described in Table 6. For all tests, strains were considered to have pathogenic potential on a plant species only if at least half of the replicate plants tested for each species showed compatible reactions.

\section{Motility and swarming}

Strains were tested for motility and swarming in soft nutrient agar composed of $15 \mathrm{~g}$ tryptone casein soy broth (Fisher Scientific, Illkirch-Graffenstaden, France) and $4 \mathrm{~g}$ agar per liter of distilled water. For each strain, $10 \mu \mathrm{L}$ of a suspension prepared in sterile distilled water from $48 \mathrm{~h}$ cultures on King's medium B (King et al. 1954) and adjusted to $10^{8} \mathrm{CFU} / \mathrm{mL}$ were deposited on each of 4 replicate plates of the soft nutrient agar in $90 \mathrm{~mm}$ Petri dishes. Plates were incubated in the dark at $25^{\circ} \mathrm{C}$ and the extent of motility and swarming were noted after 15 , 20, 27 and $48 \mathrm{~h}$ of incubation.

\section{Statistical analyses}

To identify host range patterns of strains, mean disease scores were transformed into categorical values (values of " 0 " or " 1 "). In the resulting host $\times$ pathogen matrices of these categorical data, we determined if there were structural patterns of modularity (distinct groups) or nestedness (overlapping continuum) of the host range. Such matrices containing binary data can be analyzed similarly to bipartite networks (Weitz et al. 2013). Each combination of strain and plant was assigned to category "1" (compatible host-pathogen interaction) only if symptom expression was repeatable, i.e. $\geq 3$ of the 6 plants for tests A and B inoculated with each strain showed symptoms, $\geq 3$ of the 4 plants for test $\mathrm{C}$, and $\geq 3$ of the 5 plants for test D. Otherwise the strain-plant interaction was assigned to the category " 0 ". The effect on the matrix patterns of different severity thresholds was determined for the different tests as indicated in the Results section. The nestedness and modularity of the different resulting matrices were estimated using the 'bipartite' and 'igraph' packages of R. Nestedness varies usually from 0 (low nestedness) to 1 (high nestedness) and was estimated by three different algorithms: the nestedness temperature estimator (binmatnest 2 algorithm in the $\mathrm{R}$ environment) (Rodríguez-Gironés and Santamaría 2006), the nestedness metric based on overlap and decreasing filling (NODF2 algorithm) (Almeida-Neto et al. 2008), the weighted-interaction nestedness estimator (wine algorithm) (Galeano et al. 2009) and the walktrap algorithm (Pons and Latapy 2005). Modularity varies from -1 (antimodular matrix) to +1 (high modularity matrix). 
Table 5 Plant species and cultivars used in the four different tests of this study ${ }^{\mathrm{a}}$

\begin{tabular}{|c|c|c|c|c|c|}
\hline \multirow[t]{2}{*}{ Plant species } & \multirow[t]{2}{*}{ Cultivar } & \multicolumn{4}{|l|}{ Test } \\
\hline & & A-1998 & B-2008 & C-2013 & D-2017 \\
\hline Actinidia deliciosa Liang and Ferguson & Hayward & - & - & $x$ & - \\
\hline Allium cepa $\mathrm{L}$. & Jaune Paille & $x$ & $x$ & - & $x$ \\
\hline Avena sativa $L$ & & $x$ & - & - & - \\
\hline Beta vulgaris var. cicla & Verte à carde blanche sel Bressane & - & - & - & $x$ \\
\hline Beta vulgaris var. conditiva & White Silver & - & - & - & $x$ \\
\hline Beta vulgaris var. rapa $\mathrm{L}$. & Sucrière & $x$ & - & - & $x$ \\
\hline Beta vulgaris var. rapa $\mathrm{L}$. & Ardan XS 1389 & - & $x$ & & - \\
\hline Brassica oleracea var. capitata L. & Farao & - & - & - & $x$ \\
\hline Brassica pekinense Rupr. & 106 & $x$ & - & - & - \\
\hline Capsicum annuum L. & Yolo Wonder & $x$ & $x$ & - & $x$ \\
\hline Citrullus lanatus & Sugar Baby & - & - & - & $x$ \\
\hline Corylus avellana L. and C. colurna & Tonda Gentile Romana & - & - & $x$ & - \\
\hline Cucumis melo var. cantalupensis Naud. & Védrantais & $x$ & $x$ & $x$ & $x$ \\
\hline Cucumis sativus L. CV. & Marketer & $x$ & $x$ & - & $x$ \\
\hline Cucurbita pepo var. oblonga & Tigress F1 & - & - & - & $x$ \\
\hline Glycine max (L.) Merril & Paoki & $x$ & $x$ & $x$ & - \\
\hline Helianthus annuus L. & Dogo & $x$ & $x$ & - & - \\
\hline Helianthus annuus L. & Paquito & - & - & $x$ & - \\
\hline Hordeum vulgare L. & Baronesse & $x$ & $x$ & - & - \\
\hline Lactuca sativa L. & Mantila & $x$ & $x$ & - & $x$ \\
\hline Solanum lycopersicum & Monalbo & $x$ & $x$ & $x$ & $x$ \\
\hline Nerium oleander L. & & - & - & $x$ & - \\
\hline Pelargonium hortorum & & - & - & $x$ & $x$ \\
\hline Petroselinum crispum & Géant d'Italie & - & - & - & $x$ \\
\hline Phaseolus vulgaris L. & Canadian Wonder & $x$ & $x$ & - & - \\
\hline Pisum sativum $\mathrm{L}$. & Douce Provence & $x$ & $x$ & - & $x$ \\
\hline Populus alba L. & & - & - & $x$ & - \\
\hline Prunus armeniaca L. & Manicot & - & - & $x$ & - \\
\hline Prunus cerasifera L. & Myrobolan & - & - & $x$ & - \\
\hline Prunus cerasifera X Prunus munsoniana & Mariana GF8-1 & - & - & $x$ & - \\
\hline Prunus mahaleb L. & Pontaleb & - & - & $x$ & - \\
\hline Prunus persica (L.) Stokes & Rubira & - & - & $x$ & - \\
\hline Prunus persica (L.) Stokes & Montclar & - & - & $x$ & - \\
\hline Ranunculus bulbosus L. & & - & - & $x$ & - \\
\hline Sinapis alba $\mathrm{L}$ & Bladue Architect & - & - & $x$ & - \\
\hline Solanum melongena L. & Violette & $x$ & $x$ & - & - \\
\hline Sorghum bicolor (L.) Moench. & Argence & $x$ & $x$ & - & - \\
\hline Sorghum bicolor (L.) Moench. & Solarius & - & - & $x$ & - \\
\hline Spinacia oleracea $\mathrm{L}$ & Giant d'hiver & - & - & $x$ & - \\
\hline Spinacia oleracea $\mathrm{L}$ & Andros & - & - & - & $x$ \\
\hline Trifolium pretense L. & & - & - & $x$ & - \\
\hline Triticum aestivum L. & Soisson & $x$ & - & - & - \\
\hline Triticum aestivum L. & Vic & - & $x$ & - & - \\
\hline
\end{tabular}


Table 5 Plant species and cultivars used in the four different tests of this study ${ }^{\mathrm{a}}$ (Continued)

\begin{tabular}{|c|c|c|c|c|c|}
\hline \multirow[t]{2}{*}{ Plant species } & \multirow[t]{2}{*}{ Cultivar } & \multicolumn{4}{|l|}{ Test } \\
\hline & & A-1998 & B-2008 & $C-2013$ & D-2017 \\
\hline Vicia faba $\mathrm{L}$. & Agua Dulce & - & - & $x$ & - \\
\hline Vigna unguiculata (L) Walp. & & - & - & $x$ & - \\
\hline Zea mays L. & Epi d'Or & $x$ & $x$ & - & - \\
\hline
\end{tabular}

aplants used in each test are indicated with "X" and those not used are indicated with "-"

Values close to zero correspond to random partitions of the matrix into modules of randomly distributed host cases and values are positive if the number of host cases within modules exceeds the number expected on the basis of chance. Because none of the module detection algorithms developed to date provide consistently optimal results in all matrices (Aldecoa and Marín 2013), we used four different algorithms implemented into the edge.betweenness (Brandes 2001), the spinglass.community
(Newman and Girvan 2004; Reichardt and Bornholdt 2006; Traag and Bruggeman 2009) and leading.eigenvector.community (Newman 2006) functions in the $\mathrm{R}$ software. To determine the statistical significance of the patterns (nestedness or modularity) of the plant- $P$. syringae interaction, the observed interaction matrices were compared to matrices simulated under two different null models that were generated by random assignment of compatibility between bacteria and host plants (Weitz et al. 2013): (i) in the Bernoulli

Table 6 Inoculation and incubation conditions and disease scoring scales used in the four tests of this study

\begin{tabular}{|c|c|c|c|c|}
\hline Test & A-1998 & B-2008 & $C-2013$ & D-2017 \\
\hline \multicolumn{5}{|l|}{ Date of inoculations } \\
\hline Block 1 & Feb-June 1998 & Mar-June 2008 & Mar-June 2013 & May-June 2017 \\
\hline Block 2 & May-Sept 1998 & July-Nov 2008 & & \\
\hline $\begin{array}{l}\text { \# Plants/spp./ } \\
\text { strain/block }\end{array}$ & 3 & 3 & 4 & 5 \\
\hline $\begin{array}{l}\text { Total \# plants } \\
\text { tested/ strain/ } \\
\text { plant species }\end{array}$ & 6 & 6 & 4 & 5 \\
\hline Age of plants & \multicolumn{2}{|c|}{$\begin{array}{l}\text { Dicots: 2-leaf stage } \\
\text { ( } 2 \text { trifoliate leaves for bean } \\
\text { plants), except peas which } \\
\text { were inoculated at the } \\
\text { 4-leaf stage. } \\
\text { Monocots: } 2-3 \text { leaf stage. }\end{array}$} & $\begin{array}{l}\text { Annual plants: one month after } \\
\text { sowing (3 to } 5 \text { true leaves); } \\
\text { 2-year-old Prunus spp.; } \\
\text { 3-month-old hazelnut, kiwifruit, } \\
\text { oleander and poplar plants }\end{array}$ & $\begin{array}{l}\text { All plants: one month } \\
\text { after sowing ( } 2-6 \text { true leaves) }\end{array}$ \\
\hline $\begin{array}{l}\text { Inoculum } \\
\text { concentration }\end{array}$ & \multicolumn{2}{|c|}{$5 \times 10^{7}$ to $1 \times 10^{8} \mathrm{CFU} / \mathrm{mL}$} & $10^{8} \mathrm{CFU} / \mathrm{mL}$ & $10^{8} \mathrm{CFU} / \mathrm{mL}$ \\
\hline $\begin{array}{l}\text { Inoculation } \\
\text { of herbaceous } \\
\text { plants }\end{array}$ & \multirow{2}{*}{\multicolumn{2}{|c|}{$\begin{array}{l}\text { Infiltration in leaf blade near } \\
\text { the base of the leaf } \\
(\text { ca. } 50 \mu \mathrm{L})\end{array}$}} & $\begin{array}{l}10 \text { droplets }(10 \mu \mathrm{L}) \text { on a leaf } \\
\text { and } 1 \text { droplet }(10 \mu \mathrm{L}) \text { injected } \\
\text { into stem on each plant. }\end{array}$ & $\begin{array}{l}\text { Infiltration in leaf blade near the } \\
\text { base of the leaf }(10 \mu \mathrm{L}) \text { after } \\
\text { wounding the site with a sterile } \\
\text { plastic stick. }\end{array}$ \\
\hline $\begin{array}{l}\text { Inoculation of } \\
\text { woody plants }\end{array}$ & & & $\begin{array}{l}1 \text { droplet }(10 \mu \mathrm{L}) \text { on a scar at the } \\
\text { petiole-stem junction, } \\
\text { sealed with parafilm. }\end{array}$ & \\
\hline Scoring method & \multicolumn{2}{|c|}{$\begin{array}{l}\text { 0: apparent no reaction; } \\
\text { 1: HR-like reaction that does } \\
\quad \text { not evolve; } \\
\text { 2: symptoms on < half of leaf; } \\
\text { 3: symptoms on > half of the } \\
\text { leaf blade. }\end{array}$} & $\begin{array}{l}\text { 0: no apparent reaction; } \\
\text { 1: < } 5 \text { lesions/leaf, no symptoms on stems; } \\
\text { 2: } 5 \text {-10 lesions/leaf, no symptoms on stems; } \\
\text { 3: > } 10 \text { lesions/leaf, no symptoms on stems; } \\
\text { 4: some dead leaves, no symptoms on stems; } \\
\text { 5: leaf score } 1 \text { with lesions on stems or petioles } \\
\quad \text { < } 5 \mathrm{~mm} \text { long; } \\
\text { 6: leaf score } 2 \text { with lesions on stem or petiole } \\
\quad \text { from } 5 \text { to } 10 \mathrm{~mm} \text {; } \\
\text { 7: leaf score } 3 \text { with necrosis on stem or petiole } \\
\quad>10 \mathrm{~mm} \text {; } \\
\text { 8: dead plant }\end{array}$ & $\begin{array}{l}\text { 0: no apparent reaction; } \\
\text { 1: weak symptoms, no necrosis; } \\
\text { 2: necrosis at point of inoculation } \\
\quad \text { without spreading; } \\
\text { 3:-necrosis up to } 25 \% \text { of leaf blade; } \\
\text { 4: necrosis from } 25 \text { to } 50 \% \text { of leaf blade; } \\
\text { 5: necrosis for }>50 \% \text { of leaf blade; } \\
\text { 6: wilting of entire leaf. }\end{array}$ \\
\hline $\begin{array}{l}\text { Scoring dates } \\
\text { (days after inoculation) }\end{array}$ & \multicolumn{2}{|l|}{2 and 7 days } & $\begin{array}{l}\text { Herbaceous plants: 5, } 10 \text { and } 15 \text { days. } \\
\text { Woody plants: } 15,30,45,60 \text { days }\end{array}$ & 2 and 6 days \\
\hline
\end{tabular}


random null model, the same total number of infection/disease cases as in the actual matrix was randomly distributed in matrices containing the same number of lines and columns as the actual matrix, (ii) in the probabilistic degree null model, each plant- $P$. syringae combination of the matrix was assigned a probability of corresponding to an infection/disease case which was equal to the mean of the frequencies of infection/disease cases in the same column and in the same line of the matrix (Bascompte et al. 2003; Weitz et al. 2013). Estimates of nestedness and modularity were contrasted with those of 1000 and 100 matrices simulated under both null models, respectively. Other statistical tests were conducted with Statistica (v.10, StatSoft, Inc., Tulsa, Oklahoma, USA).

\section{Additional files}

Additional file 1: Figure S1. Host range relative to phylogenetic context of strains of Pseudomonas syringae (upper figures) or ordered by rank of increasing host range and increasing number of pathogens per plant (lower figures) for each of the four independent inoculation tests. Phylogenetic trees are Neighbor-joining trees based on partial sequences of the cts (citrate synthase) gene, $413 \mathrm{bp}$. (XLSX $58 \mathrm{~kb}$ )

Additional file 2: Table S1. Strains of Pseudomonas syringae used in this study, the substrates from which they were isolated and the sources from which they were obtained or that described them previously. Strains that were tested for motility and for which whole genome sequences were obtained are indicated. (XLSX $21 \mathrm{~kb}$ )

Additional file 3: Table S2. Conditions of tests reported in the literature to determine pathogenicity of strains of Pseudomonas syringae to hosts in addition to the plant species from which strains were isolated. (DOCX $54 \mathrm{~kb})$

\section{Abbreviations}

cts: citrate synthase; PG: Phylogroup

\section{Acknowledgements}

We thank the staff of the INRA Plant Pathology Research Unit who manage the greenhouses and growth chambers, led by J. Beraud, and who, over the past several decades, have assured the production and maintenance of plants and the growth facilities that allowed us to do this work unencumbered over the past 20 years. We also thank the technicians at the INRA Plant Pathology Research Unit who maintain our vast culture collection and who assure quality gene sequencing for phylogenetic analyses, in particular C. Guilbaud, C. Chandeysson and C. Glaux (retired 2013). We are grateful to J. Dangl (University of North Carolina) for providing us several dozen strains, characterized here, for which whole genome sequences are available.

\section{Funding}

The research for this work was supported by in-house funding from INRA and from the Ministry of Education, Science and Technological Development of Serbia, grant No. 173026. The salary of JRL was supported by DAFNE, University of Tuscia. The sojourn of IN to conduct pathogenicity tests in Avignon was supported by a Research Grant from the Federation of European Microbiology Societies.

\section{Availability of data and materials}

All primary data that are not published with this work - either as tables, figures or supplemental material - can be obtained from the corresponding author. Strains that we have isolated and that are not part of exclusive contracts can be obtained from the authors. Strains that are from other culture collections can be obtained directly from those collections.

\section{Authors' contributions}

CEM established the strain collections for tests A and B and conducted these host range tests; JRL established the strain collection for test $C$ and conducted this test; IN and SS established the collection for test D and IN conducted this test. CEM conducted motility tests, obtained genome sequence data and conducted statistical analyses on these data. CEM also constructed all phylogenetic trees. BM adapted the nested and modularity tests for this work and with CEM they analyzed patterns of host range. CEM wrote the first draft of the manuscript and all authors contributed to the final version. All authors read and approved the final manuscript.

\section{Ethics approval and consent to participate}

This study did not involve any human subjects or data about their reactions. For work with plants and bacteria, all tests respected the local and national guidelines and legislations for handling and disposing bacteria and inoculated plant material and respected national policies for hygiene, security and traceability.

\section{Consent for publication}

Not applicable.

\section{Competing interests}

The authors declare that they have no competing interests.

\section{Author details}

'Plant Pathology Research Unit 407, PACA Research Center, INRA, Montfavet 84143, France. ${ }^{2}$ INRA, UMR AGIR, CS52627, 31326 Castanet-Tolosan, France.

${ }^{3}$ Faculty of Biology, University of Belgrade, Studentski trg 16, Belgrade 11000, Serbia.

Received: 24 July 2018 Accepted: 10 October 2018

Published online: 16 January 2019

\section{References}

Aldecoa R, Marín I. Exploring the limits of community detection strategies in complex networks. Sci Rep. 2013;3:2216.

Almeida-Neto M, Guimarães P, Guimarães PR Jr, Loyola RD, Ulrich W. A consistent metric for nestedness analysis in ecological systems: reconciling concept and measurement. Oikos. 2008;117:1227-39.

Arnison PG, Bibb MJ, Bierbaum G, Bowers AA, Bugni TS, Bulaj G, et al. Ribosomally synthesized and post-translationally modified peptide natural products: overview and recommendations for a universal nomenclature. Nat Prod Rep. 2013;30:108-60

Baltrus DA, Nishimura MT, Romanchuk A, Chang JH, Mukhtar MS, Cherkis K, et al. Dynamic evolution of pathogenicity revealed by sequencing and comparative genomics of 19 Pseudomonas syringae isolates. PLoS Pathog. 2011;7:e10e02132.

Bascompte J, Jordano P, Melián CJ, Olesen JM. The nested assembly of plantanimal mutualistic networks. Proc Natl Acad Sci U S A. 2003;100:9383-7.

Berge O, Monteil CL, Bartoli C, Chandeysson C, Guilbaud C, Sands DC, et al. A user's guide to a data base of the diversity of Pseudomonas syringae and its application to classifying strains in this phylogenetic complex. PLoS One. 2014;9(9):e10554e7.

Brandes U. A faster algorithm for betweenness centrality. J Math Sociol. 2001;25:163-77.

Cheng FF, Ma AZ, Luo JX, Zhuang XL, Zhuang GQ. N-acylhomoserine lactoneregulation of genes mediating motility and pathogenicity in Pseudomonas syringae pathovar tabaci 11528. MicrobiologyOpen. 2017;6:e440.

Cintas NA, Koike ST, Bull CT. A new pathovar, Pseudomonas syringae pv. alisalensis pv. Nov., proposed for the causal agent of bacterial blight of broccoli and broccoli raab. Plant Dis. 2002;86:992-8.

Cunniffe NJ, Koskella BE, Metcalf CJ, Parnell S, Gottwald TR, Gilligan CA. Thirteen challenges in modelling plant diseases. Epidemics. 2015;10:6-10.

Destéfano SAL, Rodrigues LMR, Beriam LOS, Patricio FRA, Thomaziello RA, Rodrigues-Neto J. Bacterial leaf spot of coffee caused by Pseudomonas syringae pv. tabaci in Brazil. Plant Pathol. 2010;59:1162-3.

Dordas C. Role of nutrients in controlling plant diseases in sustainable agriculture. A review. Agron Sustain Dev. 2008;28:33-46.

Galeano J, Pastor JM, Iriondo JM. Weighted-interaction Nestedness estimator (WINE): a new estimator to calculate over frequency matrices. Environ Model Softw. 2009;24:1342-6. 
Gomila M, Busquets A, Mulet M, García-Valdés E, Lalucat J. Clarification of taxonomic status within the Pseudomonas syringae species group based on a phylogenomic analysis. Front Microbiol. 2017:8:2422.

Hendson M, Hildebrand DC, Schroth MN. Relatedness of Pseudomonas syringae pv. tomato, Pseudomonas syringae pv. maculicola, and Pseudomonas syringae pv. antirrhini. J Appl Bacteriol. 1992;73:455-64.

Hirano SS, Upper CD. Bacteria in the leaf ecosystem with emphasis on Pseudomonas syringae, a pathogen, ice nucleus, and epiphyte. Microbiol Mol Biol Rev. 2000;64:624-53.

Ichinose Y, Sawada T, Matsui H, Yamamoto M, Toyoda K, Noutoshi Y, et al. Motility-mediated regulation of virulence in Pseudomonas syringae. Physiol Mol Plant Pathol. 2016;95:50-4

Ingle RA, Carstens M, Denby KJ. PAMP recognition and the plant-pathogen arms race. BioEssays. 2006;28:880-9.

Ishiyama Y, Yamagishi N, Ogiso H, Fujinaga M, Takikawa Y. Bacterial brown spot on Avena storigosa Schereb. Caused by Pseudomonas syringae pv. alisalensis. Gen Plant Pathol. 2013;79:155-7.

King EO, Ward MK, Raney DE. Two simple media for the demonstration of pyocyanin and fluorescein. J Lab Clin Med. 1954;44:301-7.

Koike ST, Alger El, Ramos Sepulveda L, Bull CT. First report of bacterial leaf spot caused by Pseudomonas syringae pv. tomato on kale in California. Plant Dis. 2017;101:504

Lamichhane JR, Messéan A, Morris CE. Insights into epidemiology and control of diseases of annual plants caused by the Pseudomonas syringae species complex. J Gen Plant Pathol. 2015:81:331-50.

Lamichhane JR, Varvaro L, Parisi L, Audergon JM, Morris CE. Disease and frost damage of woody plants caused by Pseudomonas syringe: seeing the forest for the trees. In: Spark DL, editor. Advances in agronomy, vol. 126. Cambridge: Elsevier: Academic Press; 2014. p. 235-95.

Lindeberg M, Cunnac S, Collmer A. The evolution of Pseudomonas syringae host specificity and type III effector repertoires. Mol Plant Pathol. 2009;10:767-75.

Madden LV, Van Den Bosch FA. Population-dynamics approach to assess the threat of plant pathogens as biological weapons against annual crops: using a coupled differential-equation model, we show the conditions necessary for long-term persistence of a plant disease after a pathogenic microorganism is introduced into a susceptible annual crop. Bioscience. 2002:52:65-74.

Malvick DK, Moore LW. Population dynamics and diversity of Pseudomonas syringae on maple and pear trees and associated grasses. Phytopathology. 1988;78:1366-70

Martin-Sanz A, de la Vega MP, Murillo J, Caminero C. Strains of Pseudomonas syringae pv. syringae from pea are phylogenetically and pathogenically diverse. Phytopathology. 2013;103:673-81.

Medema MH, Kottmann R, Yilmaz P, Cummings M, Biggins JB, Blin K, et al. Minimum information about a biosynthetic gene cluster. Nat Chem Biol. 2015;11:625-31.

Monteil CL, Bardin M, Morris CE. Features of air masses associated with the deposition of Pseudomonas syringae and Botrytis cinerea by rain and snowfall. ISME J. 2014;8:2290-304.

Monteil CL, Lafolie F, Laurent J, Clement JC, Simler R, Travi Y, et al. Soil water flow is a source of the plant pathogen Pseudomonas syringae in subalpine headwaters. Environ Microbiol. 2013;16:2038-52.

Monteil CL, Yahara K, Studholme DJ, Mageiros L, Méric G, Swingle B, et al. Population genomic insights into emergence, crop-adaptation and dissemination of Pseudomonas syringae pathogens. Microb Genom. 2016; 2(10):e000089.

Morris CE, Barny MA, Berge O, Kinkel LL, Lacroix C. Frontiers for research on the ecology of plant-pathogenic bacteria: fundamentals for sustainability. Mol Plant Pathol. 2017:18:308-19.

Morris CE, Glaux C, Latour X, Gardan L, Samson R, Pitrat M. The relationship of host range, physiology, and genotype to virulence on cantaloupe in Pseudomonas syringae from cantaloupe blight epidemics in France. Phytopathology. 2000;90:636-46.

Morris CE, Monteil CL, Berge O. The life history of Pseudomonas syringae: linking agriculture to earth system processes. Annu Rev Phytopathol. 2013;51:85-104.

Morris CE, Sands DC, Vanneste JL, Montarry J, Oakley B, Guilbaud C, et al. Inferring the evolutionary history of the plant pathogen Pseudomonas syringae from its biogeography in headwaters of rivers in North America, Europe and New Zealand. MBio. 2010;1(3):e00107-10.

Morris CE, Sands DC, Vinatzer BA, Glaux C, Guilbaud C, Buffière A, et al. The life history of the plant pathogen Pseudomonas syringae is linked to the water cycle. ISME J. 2008:2:321-34.
Mucyn TS, Yourstone S, Lind AL, Biswas S, Nishimura MT, Baltrus DA, et al. Variable suites of non-effector genes are co-regulated in the type III secretion virulence regulon across the Pseudomonas syringae phylogeny. PLoS Pathog. 2014;10:e1003807.

Newberry EA, Jardini TM, Rubio I, Roberts PD, Babu B, Koike ST, et al. Angular leaf spot of cucurbits is associated with genetically diverse Pseudomonas syringae strains. Plant Dis. 2016;100:1397-404.

Newman MA, Sundelin T, Nielsen JT, Erbs G. MAMP (microbe-associated molecular pattern) triggered immunity in plants. Front Plant Sci. 2013:4:139.

Newman MEJ. Finding community structure in networks using the eigenvectors of matrices. Phys Rev E. 2006;74:036104.

Newman MEJ, Girvan M. Finding and evaluating community structure in networks. Phys Rev E. 2004;69:026113.

O'Brien HE, Thakur S, Gong Y, Fung P, Zhang J, Yuan L, et al. Extensive remodeling of the Pseudomonas syringae pv. avellanae type III secretome associated with two independent host shifts onto hazelnut. BMC Microbiol. 2012;12:141.

Pfeilmeier S, Caly DL, Malone JG. Bacterial pathogenesis of plants: future challenges from a microbial perspective. Mol Plant Pathol. 2016:17:1298-313.

Polizzi G, Castello I, Parlavecchio G, Cirvilleri G. First report of bacterial blight of Strelitzia augusta caused by Pseudomonas syringae pv. lachrymans. Plant Dis. 2005:89:1010.

Pons $\mathrm{P}$, Latapy M. Computing communities in large networks using random walks (long version). In: Yolum P, Güngör T, Gürgen F, Özturan C, editors. Computer and information sciences - ISCIS, vol. 2005. Heidelberg: Springer Berlin Heidelberg; 2005. p. 20.

Reichardt J, Bornholdt S. Statistical mechanics of community detection. Phys Rev E. 2006;74:016110.

Riffaud CMH, Morris CE. Detection of Pseudomonas syringae pv. aptata in irrigation water retention basins by immunofluorescence colony staining. Eur J Plant Pathol. 2002;108:539-45.

Rodríguez-Gironés MA, Santamaría L. A new algorithm to calculate the nestedness temperature of presence-absence matrices. J Biogeogr. 2006;33:924-35.

Sarkar SF, Gordon JS, Martin GB, Guttman DS. Comparative genomics of hostspecific virulence in Pseudomonas syringae. Genetics. 2006:174:1041-56.

Sedighian N, Shams-Bakhsh M, Osdaghi E, Khodaygan P. Etiology and host range of bacterial leaf blight and necrosis of squash and muskmelon in Iran. J Plant Pathol. 2014;96:507-14.

Stopelli E, Conen F, Guilbaud C, Zopfi J, Alewell C, Morris CE. Ice nucleators, bacterial cells and Pseudomonas syringae in precipitation at Jungfraujoch. Biogeosciences. 2017;14:1189-96.

Traag V, Bruggeman J. Community detection in networks with positive and negative links. Phys Rev E. 2009;80:036115.

Velásquez AC, Castroverde CDM, He SH. Plant-pathogen warfare under changing climate conditions. Curr Biol. 2018;28:R619-34.

Venieraki A, Tsalgatidou PC, Georgakopoulos DG, Dimou M, Katinakis P. Swarming motility in plant-associated bacteria. Hell Plant Prot J. 2016;9:16-27.

Versalovic J, Koeuth T, Lupski JR. Distribution of repetitive DNA, sequences in eubacteria and application to fingerprinting of bacterial genomes. Nucleic Acids Res. 1991;19:6823-31.

Weitz JS, Poisot T, Meyer JR, Flores CO, Valverde S, Sullivan MB, et al. Phagebacteria infection networks. Trends Microbiol. 2013;21:82-91.

Xin XF, Kvitko B, He SY. Pseudomonas syringae: what it takes to be a pathogen. Nat Rev Microbiol. 2018;16:316-28.

Young JM, Bull CT, De Boer SH, Firrao G, Gardan L, Saddler GE, et al. International standards for naming pathovars of phytopathogenic bacteria. 2001. http:// www.isppweb.org/about tppb naming.asp. Accessed 28 May 2018.

Ready to submit your research? Choose BMC and benefit from:

- fast, convenient online submission

- thorough peer review by experienced researchers in your field

- rapid publication on acceptance

- support for research data, including large and complex data types

- gold Open Access which fosters wider collaboration and increased citations

- maximum visibility for your research: over $100 \mathrm{M}$ website views per year

At $\mathrm{BMC}$, research is always in progress.

Learn more biomedcentral.com/submission 